УДК 543.51-543.54

\title{
ОСОБЕННОСТИ ХИМИЧЕСКОГО СОСТАВА РАСТЕНИЙ ПРЕСНОВОДНОГО КАРБОНАТНОГО ОЗЕРА ПОДТАЙГИ
} ЗАПАДНОЙ СИБИРИ

() О.В. Серебренникова ${ }^{1,2}$, Е.Б. Стрельникова ${ }^{1}$, Е.В. Гулая ${ }^{1}$, П.Б. Кадычагов Ю.И. Прейс ${ }^{3}$ М.А. Дучко ${ }^{* 1}$

${ }^{1}$ Институт химии нефрти СО РАН, пр. Академический, 4, Томск, 634021

(Россия)

${ }^{2}$ Национальный исследовательский Томский политехнический университет, пр. Ленина, 30, Томск, 634050 (Россия)

${ }^{3}$ Институт мониторинга климатических и экологических систем СО РАН, пр. Академический, 10/3, Томск, 634055 (Россия), e-mail: maria.duchko@gmail.com

Методом газовой хроматографии-масс-спектрометрии исследован состав органических соединений в некоторых водных и прибрежноводных растениях пресноводного подтаежного озера Кирек - харе, рдесте и рогозе. Идентифицированы следующие группы соединений: алканы нормального строения, полициклоароматические углеводороды, сескви-, ди- и тритерпены, жирные кислоты, их метиловые эфиры, альдегиды, ациклические и алициклические кетоны, ациклические, алициклические и ароматические спирты, фосфаты, фураны и тиофены. Представлено распределение углеводородов и кислородсодержащих соединений в различных тканях растений (корни и листья). Выявлены некоторые особенности химического состава стероидов и тритерпеноидов водных растений - присутствие во всех образцах спиртов и кетонов стероидного строения, а в рдесте, наряду с ними, пентациклических терпеноидов ряда олеана с кетогруппой, отсутствие в харе и рогозе производных олеана.

Ключевые слова: водные растения, хромато-масс-спектрометрия, н-алканы, полициклоароматические углеводороды, терпеноиды, стероиды, жирные кислоты, кетоны, альдегиды.

Работа выполнена при финансовой поддержке грантов РФФИ №12-05-00870.

\section{Введение}

Подтайга является переходной природной зоной от южной тайги к лесостепи или широколиственным лесам. Для нее характерны хвойно-широколиственные, лиственничные и сосново-мелколиственные

Серебренникова Ольга Викторовна - доктор химических наук, профессор, заведующая лабораторией Природных превращений нефти, e-mail: ovs@ipc.tsc.ru

Стрельникова Евгения Борисовна - младший научный сотрудник, кандидат химических наук,

e-mail: seb9@yandex.ru

Гулая Елена Владимировна - кандидат химических наук младший научный сотрудник, e-mail: egulaya@yandex.ru Кадычагов Петр Борисович - кандидат химических наук, научный сотрудник, e-mail: pkad@ipc.tsc.ru Прейс Юлия Ивановна - кандидат биологических наук, старший научный сотрудник, e-mail: preisyui @imces.ru Дучко Мария Александровна - аспирант, e-mail: maria.duchko@gmail.com леса, а также густой травяной покров. Видовое разнообразие подтаежной растительности дает огромные возможности для ее изучения.

Харофитовые - линия пресноводных зеленых водорослей. Их влияние на гидрологический режим и биологические особенности водоемов весьма значительно, так как они обычно разрастаются в массе, нередко покрывая сплошной зарослью все дно водоема [1]. Весьма значительна роль харовых водорослей в природе как источника превосходной пищи для водоплавающей птицы. При больших естественных скоплениях остатков хары в аллювиаль-

\footnotetext{
* Автор, с которым следует вести переписку.
} 
ных отложениях они могут использоваться в качестве лечебных грязей или как прекрасный фильтрующий материал для очистки тяжелых органических жидкостей, например, при сахароварении [2].

Рогоз - прибрежноводное растение с широким ареалом распространения, его можно встретить по берегам всех таежных водоемов. Корни рогоза представляют собой белые нитчатые пучки, они съедобны. Само соцветие рогоза весьма ценно в качестве растопочного материала. Пух из коричневого початка можно использовать для набивки матрасов и подушек, а также вместо ваты; из него получают целлюлозу и вырабатывают бумагу [1].

Рдест относится к многолетним водным растениям, он распространен в пресных или слабосолоноватых водоемах, начинает развиваться, закрепляя свои корни на дне водоема, выпускает длинные побеги, растущие до самой поверхности воды. Рдест обладает бактерицидным действием, а благодаря сложным по составу ароматическим веществам он наделен также кровоостанавливающими и противовоспалительными свойствами. Настой листьев используется как противоцинготное средство, при желудочно-кишечных коликах, а наружно - при лечении нарывов, язв, лишаев и в качестве ранозаживляющего средства [1].

Широкое применение водных и прибрежноводных растений в медицине обусловлено биологической активностью их компонентов, которая во многом определяется содержанием стероидов. В отличие от многих других циклических соединений, имеющих плоскую структуру, стероиды характеризуются трехмерной пространственной конфигурацией, особенности которой оказывают существенное влияние на их биологическую активность. Поэтому исследование химического состава водных растений является важной и актуальной задачей.

\section{Экспериментальная часть}

В качестве объектов исследования были выбраны растения таежного озера Кирек - Хара ломкая (Chara fragilis Desv.), Рдест пронзеннолистный (Potamogeton perfoliatus L.) и Рогоз широколистный (Турha latifolia L.). Непосредственно перед анализом растения были высушены и измельчены. Корни и листья рогоза анализировали отдельно.

Органические компоненты выделяли из растений экстракцией хлороформом при $60{ }^{\circ} \mathrm{C}$. Молекулярный состав органических соединений исследовали методом газовой хроматографии-масс-спектрометрии с использованием магнитного хромато-масс-спектрометра DFS фирмы «Thermo Scientific» (Германия). Содержание отдельных структур определяли по площади соответствующих пиков на хроматограммах с использованием внутреннего стандарта и поправочных коэффициентов, определенных для каждого класса соединений.

\section{Обсуждение результатов}

В исследованных водных растениях были выявлены следующие группы углеводородов (УВ): н-алканы, полициклоароматические углеводороды (ПАУ), сескви-, ди- и тритерпены. Концентрации этих соединений представлены в таблице 1 .

н-Алканы содержатся в растениях в самых высоких концентрациях по сравнению с другими УВ. Максимальным содержанием $\boldsymbol{H}$-алканов среди исследованных растений характеризуется рдест, а минимальным - листья рогоза. Молекулярно-массовое распределение (ММР) н-алканов в исследованных растениях имеет различный характер (рис. 1).

Среди $\boldsymbol{H}$-алканов хары и листьев рогоза преобладает гомолог $\mathrm{C}_{17}$, дополнительный максимум приходится на $\mathrm{C}_{29}$. В рдесте максимум распределения выпадает на гомолог состава $\mathrm{C}_{31}$, а в корнях рогоза - на $\mathrm{C}_{29}$.

Таблица 1. Содержание отдельных классов углеводородов в растениях, мкг/г

\begin{tabular}{l|c|c|c|c}
\hline \multicolumn{1}{c|}{ Группа соединений } & \multirow{2}{*}{ Хара } & Рдест & Корни & Листья \\
\hline н-алканы & & 2,145 & 0,608 & 0,072 \\
Бициклические ПАУ & 0,394 & 0,011 & 0,004 & 0,001 \\
Трициклические ПАУ & 0,004 & 0,009 & 0,015 & 0,002 \\
Тетрациклические ПАУ & 0,013 & 0,001 & $<0,001$ & $<0,001$ \\
Терпены & 0,001 & 0,096 & 0,015 & 0,006 \\
\hline
\end{tabular}




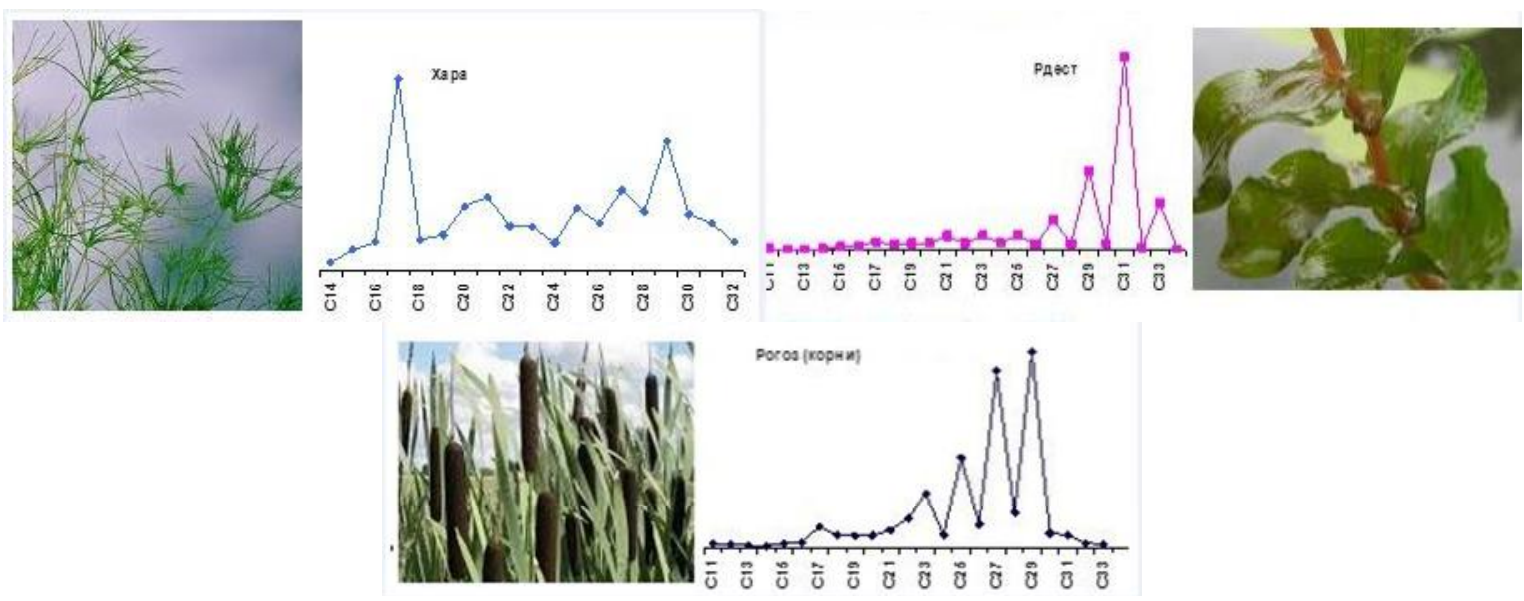

Рис. 1. Молекулярно-массовое распределение $н$-алканов в водных растениях

Содержание ПАУ во всех исследованных растениях близкое и относительно невысокое. Бициклические ПАУ представлены нафталином, его метил-, диметил-, триметил-, тетраметилзамещенными гомологами и кадаленом, трициклические - фенантреном, его метил-, диметил-, триметил-, тетраметилзамещенными гомологами и ретеном, а тетрациклические - флуорантеном и пиреном. Структуры некоторых ПАУ представлены на рисунке 2.

Хара и рогоз (корни и листья) характеризуются самым высоким содержанием трициклических ПАУ, а рдест - бициклических. Среди бициклических ПАУ в большинстве растений преобладают триметилзамещенные нафталины, только в листьях рогоза доминируют нафталины с одним метильным заместителем. Максимальным содержанием кадалена, как и нафталинов, характеризуется рдест. Среди фенантренов в харе преобладают незамещенный фенантрен и его монометилзамещенные гомологи, в рдесте - триметилзамещенные, в корнях рогоза доминирует незамещенный фенантрен, а в его листьях - метилфенантрены. Ретен присутствует во всех образцах растений в существенно более низкой, чем кадален, концентрации. Содержание тетрациклических флуорантена и пирена невысокое.

В исследованных озерных растениях идентифицировано 12 сесквитерпенов, структуры которых представлены на рисунке 3. Каламенен, $\alpha$ - и $\beta$-калакорены, а также алициклический $\delta$-кадинен являются единственными представителями сесквитерпеноидов в корнях рогоза, в листьях присутствует также 1-изопропил-4,7-диметил-1,2,3,4,6,8 $\alpha$-гексагидронафталин. Это соединение, а также $\alpha$-кубебен, гермакрен, $\alpha$-аморфен и $\alpha$-мууролен зафиксированы в харе и рдесте. В рдесте, кроме того, идентифицированы $\beta$-кубебен, юнипен, 8-изопропил-5-метил-2-метилен-1,2,3,4,4 $, 5,6,6,7$-октагидронафталин, $\beta$-селинен и $\gamma$-кадинен, отсутствующие в остальных растениях. Общее содержание сесквитерпеноидов снижается в ряду рдест хара - корни рогоза - листья рогоза.

Среди кислородсодержащих органических соединений (КОС) в растениях обнаружены жирные кислоты нормального строения, их метиловые эфиры, альдегиды, кетоны, спирты, фосфаты, фураны и тиофены. Кетоны включают ациклические соединения нормального и изопреноидного строения, а также алициклические структуры с двумя, четырьмя и пятью циклами. Среди спиртов, наряду с алифатическими, идентифицированы соединения с ароматическими циклами. Фосфаты представлены трифенилэфирами фосфорной кислоты, а альдегиды, обнаруженные только в рдесте - ациклическими структурами нормального строения. Среди фуранов идентифицированы метилдигидрофуранон $\mathrm{C}_{21}$ и метилфуран $\mathrm{C}_{20}$ с алкильными цепями изопреноидного строения, среди тиофенов - метилпентадецилтиофены состава $\mathrm{C}_{20}$, а в харе еще и изомер $\mathrm{C}_{20}$ с изопреноидной цепью (рис. 4). Содержание различных классов КОС в растениях показано в таблице 2.

Среди идентифицированных в водных растениях КОС преобладают карбоновые кислоты. Ряд жирных кислот включает в себя гомологи с числом атомов углерода от 6 до 22 с резким преобладанием молекул с четным числом атомов углерода во всех образцах, причем пальмитиновая кислота $\left(\mathrm{C}_{16}\right)$ составляет более 2/3 общего количества кислот во всех растениях. Максимальное содержание карбоновых кислот характерно для хары и корней рогоза. Метиловые эфиры карбоновых кислот представлены гомологами ряда $\mathrm{C}_{12}-\mathrm{C}_{31}$ с преобладанием нечетных гомологов и доминированием среди них метилового эфира пальмитиновой кислоты. 


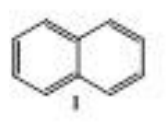<smiles>c1ccc2ccccc2c1</smiles>

III
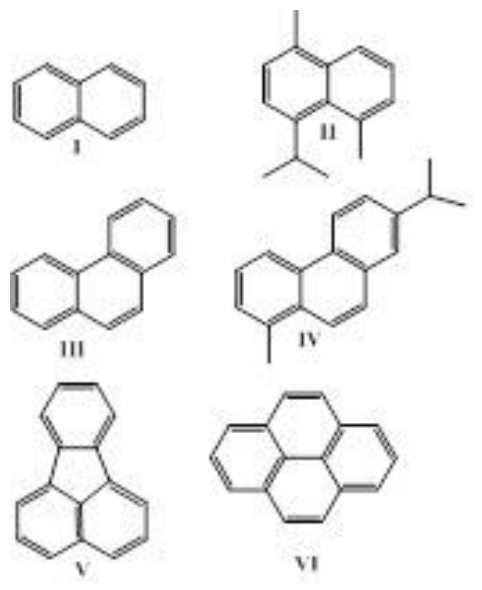

v!

Рис. 2. Структуры ПАУ, идентифицированных в растениях: I - афталин, II - кадален, III - фенантрен, IV - ретен, V - флуорантен, VI - пирен

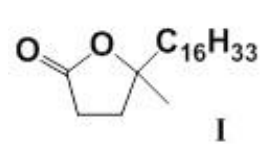<smiles>Cc1ccsc1Cc1ccccc1</smiles>

Рис. 4. Структуры гетероциклических соединений: I - 5-метил-5-(4,8,12-триметилтридецил)дигидро-2(3Н)-фуранон, II - 3-метил-2-[3,7,11-

триметилдодецил]тиофен

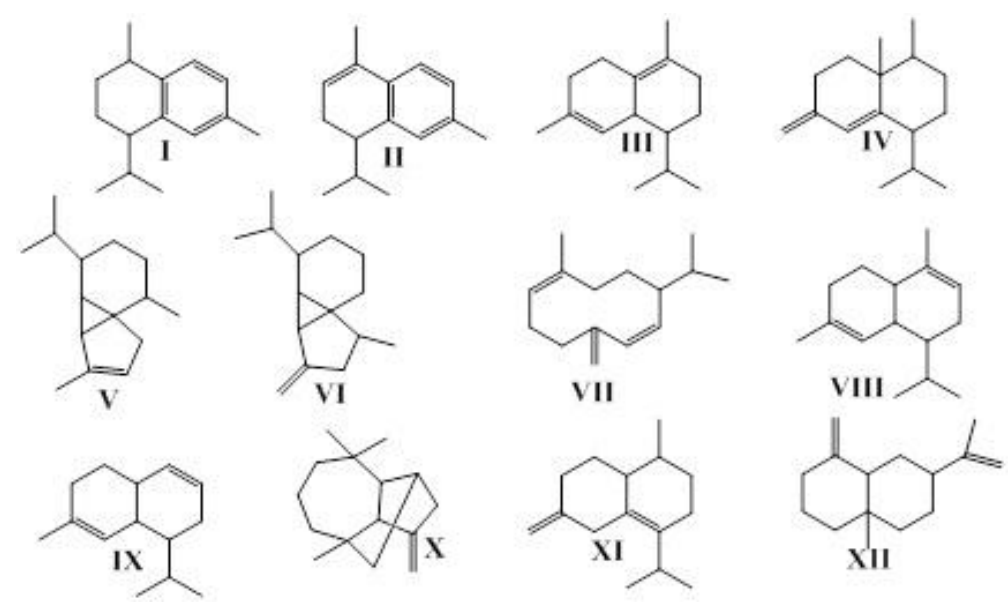

Рис. 3. Структуры сесквитерпеноидов: I - каламенен, II - $\alpha$-калакорен, III - $\delta$-кадинен, IV - 1-изопропил-4,7-диметил$1,2,3,4,6,8 \alpha$-гексагидронафталин, V - $\alpha$-кубебен, VI - $\beta$-кубебен, VII - гермакрен, VIII - $\alpha$-аморфен, IX - $\alpha$-мууролен, X - юнипен, $\mathrm{XI}$ - 8-изопропил-5-метил-2-метилен-1,2,3,4,4 $\alpha, 5,6,7$ октагидронафталин, XII - $\beta$-селинен

$\mu$-Альдегиды состава $\mathrm{C}_{20}-\mathrm{C}_{28}$ с преобладанием четных компонентов над нечетными среди водных растений были обнаружены лишь в рдесте. Максимум распределения приходится на гомологи $\mathrm{C}_{24}$ и $\mathrm{C}_{26}$.

Серия $\boldsymbol{H}$-алкан-2-онов была определена в диапазоне $\mathrm{C}_{14}-\mathrm{C}_{33}$ со значительным преобладанием нечетных гомологов над четными. Характерно наличие двух максимумов - основного $\mathrm{C}_{17}$ и дополнительного $\mathrm{C}_{27}\left(\mathrm{C}_{33}\right.$ для рдеста). Концентрация изопреноидных кетонов (6,10,14-триметилпента-декан-2-она и 6,10 диметилундекан-2-она) в несколько раз превышает содержание $н$-алканонов.

Молекулярно-массовое распределение КОС нормального строения представлено на рисунке 5.

Таблица 2. Содержание отдельных групп КОС в растениях

\begin{tabular}{|c|c|c|c|c|}
\hline \multirow{2}{*}{ Группа соединений } & \multirow{2}{*}{ Xара } & \multirow{2}{*}{ Рдест } & \multicolumn{2}{|c|}{ Рогоз } \\
\hline & & & Корни & Листья \\
\hline \multicolumn{5}{|c|}{ Содержание, мкг/г сухого растения } \\
\hline Кислоты & 2,935 & 0,634 & 2,863 & 0,526 \\
\hline Эфиры & 0,039 & 0,024 & 0,044 & 0,008 \\
\hline Альдегиды & 0 & 0,109 & 0 & 0 \\
\hline Кетоны & 0,040 & 0,121 & 0,046 & 0,009 \\
\hline ациклические & 0,029 & 0,049 & 0,021 & 0,008 \\
\hline алициклические & 0,011 & 0,072 & 0,025 & 0,001 \\
\hline Спирты & 1,125 & 0,165 & 0,262 & 0,181 \\
\hline ациклические & 1,026 & 0,050 & 0,184 & 0,170 \\
\hline алициклические & 0,066 & 0,101 & 0,052 & 0,008 \\
\hline ароматические & 0,033 & 0,013 & 0,025 & 0,003 \\
\hline Фосфаты & 0,003 & 0,001 & 0,001 & 0,000 \\
\hline Фураны & 0,047 & 0,027 & 0,026 & 0,006 \\
\hline Тиофены & 0,013 & 0,003 & 0,002 & 0,003 \\
\hline
\end{tabular}


Ароматические КОС в исследованных растениях представлены лишь $\alpha$ токоферолом и фосфатами. Во всех растениях присутствуют спирты и кетоны стероидного строения, а в рдесте, наряду с ними, пентациклические терпеноиды ряда олеана с кето-группой (табл. 3). Во всех исследованных растениях среди стероидов преобладают соединения с 29 атомами углерода в молекулах. Содержание производных холестана $\left(\mathrm{C}_{27}\right)$ снижается в ряду хара рдест - рогоз. Максимальная концентрация производных эргостана $\left(\mathrm{C}_{28}\right)$
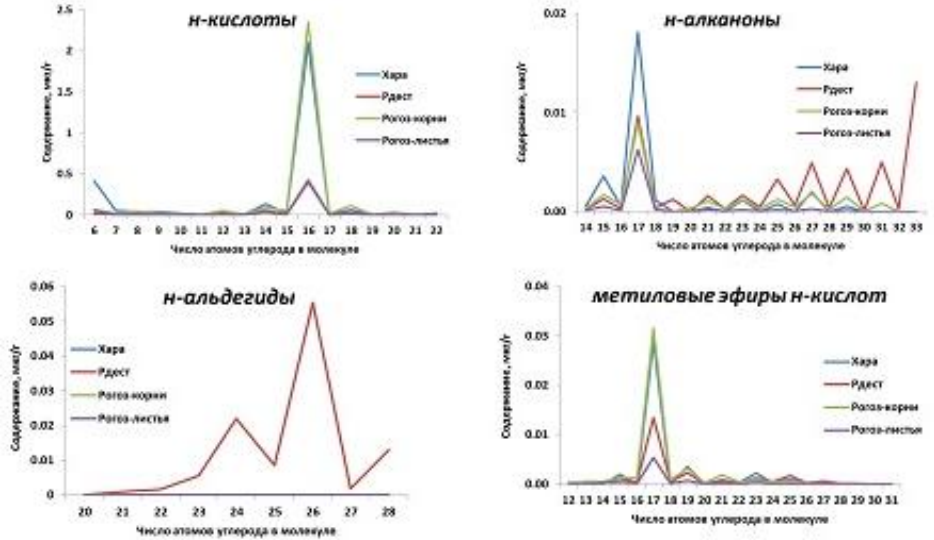

Рис. 5. Молекулярно-массовое распределение КОС в водных растениях и стигмастана зафиксирована в рдесте. Наряду с производными холестана, эростана и стигмастана, в рдесте присутствует представитель циклоартанов, а также пентациклические терпеноиды ряда олеана (рис. 6).

Таблица 3. Содержание изопреноидов в водных растениях

\begin{tabular}{|c|c|c|c|c|c|}
\hline \multirow{2}{*}{ Соединение } & \multirow{2}{*}{$\begin{array}{c}\text { Число атомов } \\
\mathrm{C} \\
\end{array}$} & \multirow{2}{*}{ Xapa } & \multirow{2}{*}{ Рдест } & \multicolumn{2}{|c|}{ Рого3 } \\
\hline & & & & Корни & Листья \\
\hline \multicolumn{6}{|c|}{ Содержание, мкг/г } \\
\hline \multicolumn{2}{|c|}{ Стероиды (сумма) } & 0,069 & 0,134 & 0,076 & 0,008 \\
\hline$\alpha$-Холестан-3-он & 27 & 0,0007 & 0 & 0 & 0 \\
\hline Холест-4-ен-3-он & 27 & 0,0005 & 0,0013 & 0,0005 & 0 \\
\hline Холест-3,5-диен-7-он & 27 & 0,0005 & 0,0001 & 0 & 0 \\
\hline Холест-4,6-диен-3-ол & 27 & 0,0053 & не опр. & не опр. & 0,0007 \\
\hline$\alpha$-Эргостан-3-он & 28 & 0 & 0 & 0,00016 & 0 \\
\hline Эргост-4-ен-3-он & 28 & 0 & 0,0035 & 0,0032 & 0 \\
\hline Эргост-3,5-диен-7-он & 28 & 0 & 0,0002 & 0 & 0 \\
\hline Эргост-4,6-диен-3-ол & 28 & 0,0024 & 0,0066 & 0,0053 & 0,0002 \\
\hline Ситостерол & 29 & 0,0028 & 0,0022 & 0,0013 & 0 \\
\hline$\alpha$-Стигмастан-3-он & 29 & 0,0011 & 0,0023 & 0,0029 & 0 \\
\hline$\beta$-Стигмастан-3-он & 29 & 0,0012 & 0,0008 & 0,0011 & 0 \\
\hline Стигмаст-4-ен-3-он & 29 & 0,0033 & 0,0377 & 0,0151 & 0,0002 \\
\hline Стигмаст-3,5-диен-7-он & 29 & 0,0042 & 0,0036 & 0,0015 & 0,0004 \\
\hline Стигмаст-4,6-диен-3-ол & 29 & 0,0471 & 0,0648 & 0,0451 & 0,0060 \\
\hline 24-Метиленциклоартан-3-он & 31 & 0 & 0,0105 & 0 & 0 \\
\hline \multicolumn{2}{|c|}{ Тритерпеноиды (сумма) } & 0 & 0,012 & 0 & 0 \\
\hline Олеан-12-ен-3-он & 30 & 0 & 0,0054 & 0 & 0 \\
\hline Урс-12-ен-3-он & 30 & 0 & 0,0068 & 0 & 0 \\
\hline
\end{tabular}

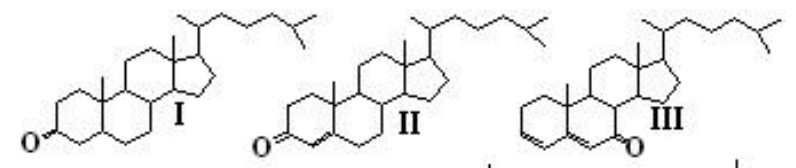

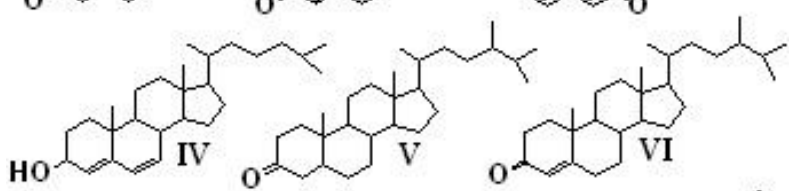

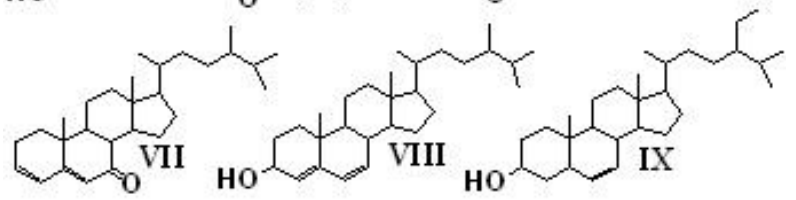

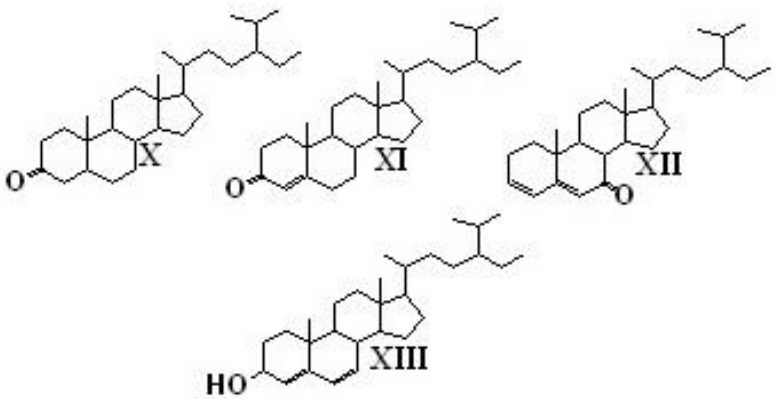

Рис. 6. Структуры стероидов, идентифицированных в растениях: I - $\alpha$-холестан-3-он, II - холест-4-ен-3он, III - холест-3,5-диен-7-он, IV - холест-4,6-диен-3-ол, V - $\alpha$-эргостан-3-он, VI - эргост-4-ен-3-он, VII - эргост-3,5-диен-7-он, VIII - эргост-4,6-диен-3-ол, IX - ситостерол, X - $\alpha$-стигмастан-3-он, XI - стигмаст-4-ен-3-он, XII - стигмаст-3,5-диен-7-он, XIII - стигмаст-4,6-диен-3-ол 


\section{Bbыводbl}

1. Исследованные водные и прибрежноводные растения содержат большой набор ациклических и алициклических углеводородов и кислородсодержащих органических соединений. Ароматические углеводороды присутствуют в малых количествах.

2. Отдельные виды растений различаются между собой и во многом отличаются от исследованных ранее растений-торфообразователей верховых болот [3, 4]. Водные растения отличаются отсутствием этиловых и изопропиловых эфиров, преобладанием в составе $\boldsymbol{H}$-алканов хары и листьев рогоза гомолога $\mathrm{C}_{17}$, отсутствием в харе и рогозе производных олеана. В составе $\boldsymbol{H}$-алканов хары и листьев рогоза преобладает гомолог $\mathrm{C}_{17}$, в корнях рогоза $-\mathrm{C}_{29}$, а в рдесте $-\mathrm{C}_{31}$. Наряду со стероидами $\mathrm{C}_{29}$ и $\mathrm{C}_{28}$ в водных растениях обнаружены производные холестана и диплоптен.

\section{Сиисок литературы}

1. Биологический энциклопедический словарь / ред. М.С. Гиляров. М., 1989. 864 с.

2. Жизнь растений: в 6 Т. / под ред. А.Л. Тахтаджяна. М., 1974.

3. Дучко М.А., Гулая Е.В., Серебреникова О.В., Стрельникова Е.Б., Прейс Ю.И. Распределение $\mu$-алканов, стероидов и тритерпеноидов в торфе и растениях болота Тёмное // Известия Томского политехнического университета. 2013. Т. 323. № 1. С. 40-44.

4. Серебреникова О.В., Гулая Е.В., Стрельникова Е.Б., Кадычагов П.Б., Прейс Ю.И., Дучко М.А. Химический состав липидов типичных растений-торфообразователей олиготрофных болот лесной зоны Западной Сибири // Химия растительного сырья. 2014. № 1. С. 257-262.

Поступило в редакичию 24 января 2014 г. После переработки 3 марта 2014 г.

Serebrennikova O.V. ${ }^{1,2}$, Strelnikova E.B. ${ }^{l}$, Gulaya E.V. ${ }^{l}$, Kadychagov P.B. ${ }^{l}$, Preis Y.I. ${ }^{3}$, Duchko M.A. ${ }^{l}$ THE CHEMICAL COMPOSITION OF FRESHWATER CARBONATED LAKE PLANTS OF WESTERN SIBERIA SUB-BOREAL FOREST

${ }^{1}$ Institute of Petroleum Chemistry SB RAS, Akademicheskii ave., 4, Tomsk, 634021 (Russia)

${ }^{2}$ National Research Tomsk Polytechnic University, Lenina ave., 30, Tomsk, 634050 (Russia)

${ }^{3}$ Institute of Monitoring of Climatic and Ecological Systems SB RAS, Akademicheskii ave., Tomsk, 634055 (Russia),

e-mail: maria.duchko@gmail.com

The paper describes the organic compounds composition of some aquatic and coastal plants, sampled on the freshwater sub-boreal forest lake Kirek - chara, pondgrass and reed mace. The distribution of hydrocarbons and oxygenated compounds in different plant tissues (roots and leaves) is presented. It is shown that all investigated plants are characterized by the presence of $n$-alkanes, polycycloaromatic hydrocarbon, sesqui-, di- and triterpenes, steroids, fatty acids, esters, aldehydes, ketones and triphenyl phosphates.

Keywords: aquatic plants, gas chromatography-mass spectrometry, n-alkanes, polycycloaromatic hydrocarbons, terpenoids, steroids, fatty acids, ketones, aldehydes.

\section{References}

1. Biologicheskij jenciklopedicheskij slovar' [Encyclopedic Dictionary of Biology]. Ed. M.S. Giljarov. Moscow, 1989, 864 p. (in Russ.).

2. Zhizn' rastenij: v 6 t. [Plant life: in 6 vol.]. Ed. A.L. Tahtadzhjana. Moscow, 1974. (in Russ.).

3. Duchko M.A., Gulaja E.V., Serebrenikova O.V., Strel'nikova E.B., Prejs Ju.I. Izvestija Tomskogo Politehnicheskogo Universiteta. [Bulletin of the Tomsk Polytechnic University]. 2013, vol. 323, no. 1, pp. 40-44. (in Russ.).

4. Serebrenikova O.V., Gulaja E.V., Strel'nikova E.B., Kadychagov P.B., Prejs Ju.I., Duchko M.A. Himija rastitel'nogo syr'ja, 2014, no. 1, pp. 257-262. 